\title{
PENERAPAN MODEL PEMBELAJARAN INKUIRI UNTUK MENINGKATKAN KETERAMPILAN PROSES SAINS SISWA KELAS VIII.1
}

\author{
Shelly Afrilia Arista ${ }^{1 *}$, Sri Irawati ${ }^{1}$, Ariefa Primairyani ${ }^{1}$ \\ ${ }^{1}$ Program Studi Pendidikan Biologi, Fakultas Keguruan dan Ilmu Pendidikan, Universitas Bengkulu \\ email : Shellyafriliaarista0104@gmail.com
}

\begin{abstract}
Abstrak
Penelitian ini bertujuan untuk mendeskripsikan aktivitas mengajar guru dan keterampilan proses sains siswa kelas VIII.1 SMP Negeri 3 Kota Bengkulu dengan menerapkan model pembelajaran inkuiri pada materi sistem ekskresi manusia. Jenis penelitian ini adalah penelitian tindakan kelas yang dilakukan dalam dua siklus dengan setiap siklusnya terdiri atas 4 tahapan yaitu: tahap perencanaan, pelaksanaan tindakan, pengamatan dan refleksi. Subyek penelitian ini yaitu guru dan siswa kelas VIII.1 SMP Negeri 3 Kota Bengkulu yang terdiri dari 20 orang siswa. Teknik pengumpulan data dalam penelitian ini adalah observasi. Instrument penelitian yaitu lembar observasi yang digunakan untuk mengamati aktivitas mengajar guru dan keterampilan proses sains siswa. Hasil penelitian dari analisa data observasi guru siklus I diperoleh skor rata-rata 23 (baik), siklus II menjadi 27 (baik). Kemudian, hasil analisis data observasi keterampilan proses sains siswa siklus I diperoleh skor rata-rata 12,4 (baik), siklus II menjadi 14,5 (baik). Dari hasil penelitian disumpulkan bahwa penerapan model pembelajaran inkuiri dapat meningkatkan keterampilan proses sains siswa kelas VIII.1 SMP Negeri 3 Kota Bengkulu.
\end{abstract}

Kata kunci : Inkuiri, Keterampilan Proses Sains.

\begin{abstract}
This study aims to describe teaching activities and science process skill students' at VIII.1 SMP Negeri 3 Kota Bengkulu by implementation of inquiry model Bengkulu on the material of human excretion system. Type of this research was a classroom action research that was conducted in two cycles and each cycle consists of four stages: planning, implementation of action, observation, and reflection. The subjects of the study were teachers and students at VIII.1 class of SMP N 3 Kota Bengkulu which was consisted of 20 students. The data were collected through observation. The research instrument was used observation sheet used to observe teaching activities and science process skill students'. The research results of the teachers' observation data analysis in cycle I obtained an average score of 23 (good), cycle II to 27 (good). Then, The result of data observation analysis of students' science proces skill, cycle I obtained an average score of 12.4 (good), cycle II to 14.5 (good). As the conclusion of this study that Inquiry learning model could improve the science process skill students' at VIII.1 class of SMP Negeri 3 Kota Bengkulu.
\end{abstract}

Keywords : Inquiry, Science Process Skill. 


\section{PENDAHULUAN}

Pembelajaran IPA digunakan sebagai alat pendidikan yang berguna untuk mencapai tujuan pendidikan. Pembelajaran IPA ini baik secara khusus maupun umum diharapkan dapat memberikan pengetahuan (kognitif) yang merupakan tujuan utama dari pembelajaran. Jenis pengetahuan yang dimaksud adalah pengetahuan dasar dari prinsip dan konsep yang bermanfaat untuk kehidupan sehari-hari. Pengetahuan secara garis besar tentang fakta yang ada di alam untuk dapat memahami dan memperdalam lebih lanjut, dan melihat adanya keterangan serta keteraturannya. Selain itu juga, pembelajaran IPA diharapkan pula memberikan keterampilan (psikomotorik), kemampuan sikap ilmiah (afektif), pemahaman, kebiasaan, dan apresiasi Laksmi (1986) dalam (Trianto, 2014).

Menurut Dahar (1999) dalam (Trianto, 2012) keterampilan-keterampilan yang diajarkan dalam pendidikan IPA memberi penekanan pada keterampilanketerampilan berpikir yang dapat berkembang pada anak-anak. Dengan keterampilan-keterampilan ini, anak-anak dapat mempelajari IPA sebanyak mereka dapat mempelajarinya dan ingin mengetahuinya. Selain keterampilan berpikir, dalam pembelajaran IPA juga diharapkan dapat mengembangkan keterampilan proses siswa.

Menurut indrawati (1999) dalam (Trianto, 2012), menjelaskan bahwa keterampilan proses merupakan keseluruhan keterampilan ilmiah yang terarah (baik kognitif maupun psikomotor) yang dapat digunakan untuk menemukan suatu konsep atau prinsip atau teori, untuk mengembangkan konsep yang telah ada sebelumnya, ataupun untuk melakukan penyangkalan terhadap penemuan/ flasifikasi.

Selain itu Trianto (2012) juga mengemukakan bahwa keterampilan proses sangatlah penting untuk dilatih/ dikembangkan bagi siswa didalam proses pembelajaran karena keterampilan proses mempunyai peran untuk membantu siswa belajar mengembangkan pikirannya, memberi kesempatan untuk melakukan penemuan, meningkatkan daya ingat, dan membantu siswa mempelajari konsepkonsep sains.

Berdasarkan hasil kegiatan magang III yang dilakukan pada tanggal 31 Oktober 2016 di kelas VIII.1 SMP Negeri 3 Kota Bengkulu menunjukkan bahwa keterampilan proses siswanya masih kurang dalam kegiatan pembelajaran seperti keterampilan mengelompokkan, dan keterampilan menggunakan alat/bahan. Hal ini terlihat pada saat siswa melakukan kegiatan percobaan mengenai identifikasi kualitas produk tanah liat. Dimana pada percobaan ini siswa sangat dituntut untuk melakukan pengamatan secara langsung untuk menentukan kualitas dari produk tanah liat yang mereka amati. Karena kurangnya keterampilan siswa dalam mengelompokkan/ mengklasifikasikan menyebabkan masih banyak siswa yang tidak dapat menentukan kualitas dari produk tanah liat berdasarkan hasil pengamatannya. Selain itu juga masih ada \pm 10 orang siswa yang belum bisa menggunakan alat percobaan seperti timbangan neraca yang digunakan untuk menimbang berat kubus, hal ini menunjukkan bahwa keterampilan siswa dalam menggunakan alat/bahan masih kurang. Sehingga menyebabkan siswa cenderung pasif dalam pembelajaran. Kurangnya arahan dari guru didalam kegiatan percobaan juga cenderung 
membuat siswa tidak dapat melatih keterampilan yang mereka miliki.

Oleh karena itu peneliti dan guru berkolaborasi untuk melakukan penelitian tentang penerapan model pembelajaran inkuiri untuk meningkatkan keterampilan proses sains siswa SMP Negeri 3 Kota Bengkulu pada materi sistem ekskresi. Menurut Hosnan (2014) model pembelajaran inkuiri adalah model pembelajaran yang menekankan siswa untuk mencari dan menemukan sendiri materi pembelajaran. Sedangkan pendidik berperan sebagai fasilitator dan pembimbing peserta didik untuk belajar. Eruce dan Weil (1980) dalam (Hosnan, 2014) menyebutkan bahwa latihan inquiry dapat menambah pengetahuan sains, menghasilkan kemampuan berpikir kreatif, menambah keterampilan dalam memperoleh dan menganalisis suatu data. Maka dari itu diharapkan dengan menerapkan model pembelajaran inkuiri ini dapat meningkatkan keterampilan proses sains siswa yakni keterampilan mengamati, mengelompokkan/ mengklasifikasikan, menggunakan alat/ bahan dan berkomunikasi yang mengacu pada Permendikbud No. 58 Tahun 2014.

\section{METODE PENELITIAN}

Jenis penelitian ini adalah penelitian tindakan kelas. Metode yang digunakan dalam penelitian ini adalah metode deskriptif. metode deskriptif digunakan untuk mendeskripsikan kegiatan pembelajaran yang dilakukan guru dengan menerapkan model pembelajaran inkuiri pada materi sistem ekskresi, keterampilan proses sains siswa. Penelitian ini dilakukan di SMP Negeri 3 Kota Bengkulu. Subyek penelitian ini adalah guru dan siswa kelas VIII.1 tahun ajaran 2016/2017, yang terdiri dari 20 orang siswa.
Instrumen yang digunakan dalam penelitian ini yaitu lembar observasi yang digunakan untuk mengetahui aktivitas mengajar guru dengan menerapkan model pembelajaran inkuiri pada materi sistem ekskresi dan keterampilan proses sains siswa.

Teknik analisis data. Data hasil observasi aktivitas mengajar guru dan keterampilan proses sains diolah secara deskriptif dengan cara mencari rata-rata dan rentang kategori. Rumus rata-rata sebagai berikut (Setyosari, 2015) :

$$
\bar{X}=\frac{\sum X}{N}
$$

Keterangan :

$$
\begin{array}{cl}
\bar{X} & =\text { Rata }- \text { rata } \\
\Sigma \mathrm{X} & =\text { Jumlah seluruh skor yang } \\
& \text { diperoleh } \\
\mathrm{N} & =\text { Jumlah observer }
\end{array}
$$

Penentuan kisaran skor setiap kategori diolah dengan menggunakan rumus menurut Sudijono (2012) sebagai berikut:

$$
\text { Rentang tiap kategori }=\frac{\text { skor tertinggi }- \text { skor terendah }}{\text { jumlah kategori }}
$$

Keterangan dari rumus yaitu :

Skor tertinggi $=$ jumlah butir pengamatan $\mathrm{x}$ skor tertinggi setiap butir

Skor terendah $=$ jumlah butir pengamatan $\mathrm{x}$ skor terendah setiap butir

Untuk memperoleh keseluruhan persentase kategori keterampilan proses sains siswa menggunakan rumus Sudijono (2014) :

$$
\mathrm{P}=\frac{f}{N} \times 100 \%
$$

Keterangan:

$\mathrm{P}=$ Angka Persentase

$\%=$ Persentase kelompok kategori

Baik/Cukup/Kurang

$F=$ Jumlah kelompok untuk kategori Baik/Cukup/Kurang 


\section{HASIL DAN PEMBAHASAN}

Berdasarkan hasil analisis data penelitian yang telah dilakukan di kelas VIII.1 SMP Negeri 3 Kota Bengkulu berupa penerapan model pembelajaran inkuiri untuk meningkatkan keterampilan proses sains diperoleh hasil sebagai berikut :

Tabel 1 Data Hasil Observasi Guru Siklus I dan Siklus II

\begin{tabular}{cccccc}
\hline \multicolumn{6}{c}{ Aktivitas Mengajar Guru } \\
\hline Siklus & Observer & Total & $\begin{array}{c}\text { Rata- } \\
\text { rata }\end{array}$ & Kategori \\
\hline I & 23 & 23 & 46 & 23 & Baik \\
II & 27 & 27 & 54 & 27 & Baik \\
\hline
\end{tabular}

Berdasarkan tabel diatas, dapat dilihat bahwa secara keseluruhan aktivitas mengajar guru mengalami peningkatan dari siklus I ke siklus II. Peningkatan ini dapat dilihat dari skor rata-rata yang di peroleh. Pada siklus I skor rata-rata yang diperoleh yaitu 23 dengan kategori baik kemudian pada siklus II skor rata-rata yang diperoleh meningkat menjadi 27 dengan kategori baik. Peningkatan ini terjadi setelah dilakukannya perbaikan pada butir pengamatan yang dinilai cukup di siklus I. Adapun butir pengamatan yang dinilai cukup oleh dua orang observer yaitu butir pengamatan guru menyampaikan tujuan pembelajaran, melakukan apersepsi dan motivasi, membimbing siswa dalam mengumpulkan data, dan butir pengamatan guru membimbing siswa menguji hipotesis berdasarkan data yang telah dikumpulkan. Pada siklus I butir pengamatan yang dinilai cukup oleh dua orang observer sudah dinilai baik di siklus II, hal ini menunjukkan bahwa telah terjadinya peningkatan dari siklus I ke siklus II. Perbaikan butir pengamatan aktivitas mengajar guru dengan menerapkan model pembelajaran inkuiri yang dinilai cukup oleh dua orang observer, dilakukan untuk meningkatkan kegiatan pembelajaran serta meningkatkan keterampilan proses sains siswa.

Dalam penelitian ini ada 4 keterampilan proses sains yang diamati yakni keterampilan mengamati, mengelompokkan/ mengklasifikasikan, menggunakan alat/ bahan dan berkomunikasi.

Tabel 2 Data Hasil Observasi Keterampilan Proses Sains

\begin{tabular}{|c|c|c|c|c|c|}
\hline \multirow{2}{*}{ Siklus } & \multicolumn{2}{|c|}{$\begin{array}{l}\text { Keterampilan } \\
\text { Proses Sains }\end{array}$} & \multicolumn{3}{|c|}{$\begin{array}{c}\text { \% Kategori Keterampilan } \\
\text { Proses Sains }\end{array}$} \\
\hline & $\begin{array}{l}\text { Rata- } \\
\text { rata } \\
\text { Skor }\end{array}$ & $\begin{array}{c}\text { Kateg } \\
\text { ori }\end{array}$ & Baik & Cukup & Kurang \\
\hline I & 12,4 & Baik & 100 & 0 & 0 \\
\hline II & 14,5 & Baik & 100 & 0 & 0 \\
\hline
\end{tabular}

dilihat bahwa secara keseluruhan keterampilan proses sains siswa dinilai baik oleh dua orang observer di siklus I dan siklus II. Dan dapat dilihat juga bahwa terjadinya peningkatan skor rata-rata yang diperoleh. Pada siklus I skor rata-rata yang diperoleh yaitu 12,4 dengan kategori baik. Kemudian meningkat menjadi 14,5 dengan kategori baik. Pada siklus I keterampilan proses sains siswa yang termasuk kedalam kategori baik yaitu keterampilan mengamati, mengklasifikasikan/ mengelompokkan dan menggunakan alat/bahan. Sedangkan keterampilan berkomunikasi termasuk kedalam kategori cukup. Keterampilan berkomunikasi ini termasuk kedalam kategori cukup karena siswa mempresentasikan hasil percobaannya dengan cara membaca tanpa menjelaskan hasil yang diperolehnya. Hal ini selaras dengan pendapat yang dikemukakan oleh Permendikbud No. 58 Tahun 2014 dan menurut Trianto (2012) dimana ia mengemukakan bahwa didalam indikator dari keterampilan berkomunikasi siswa harus menjelaskan hasil percobaan atau hasil penelitian yang mereka peroleh dan 
mengatakan apa yang diketahui dengan ucapan kata-kata atau sesuai dengan pemahamannya. Setelah dilakukan refleksi dan tindakan perbaikan pada siklus II keterampilan berkomunikasi ini mengalami peningkatan karena pada siklus II guru meminta siswa untuk menjelaskan hasil yang mereka peroleh berdasarkan pemahamannya masing-masing.

Selain itu peningkatan keterampilan proses sains ini juga terjadi karena adanya aktivitas mengajar guru dengan menggunakan model pembelajaran inkuiri yang diperbaiki. Hal ini selaras dengan pernyataan yang dikemukakan oleh oleh Eruce dan Weil (1980) dalam (Hosnan, 2014) yang menyatakan bahwa latihan dengan menggunakan model pembelajaran inquiry dapat menambah pengetahuan sains, menambah keterampilan siswa dalam memperoleh dan menganalisis suatu data.

\section{PENUTUP}

\section{Simpulan}

Dari hasil penelitian yang telah dilakukan mengenai penerapan model pembelajaran inkuiri untuk meningkatkan keterampilan proses sains siswa kelas VIII.1 SMP Negeri 3 Kota Bengkulu pada Materi Sistem ekskresi dapat disimpulkan bahwa perbaikan pembelajaran termasuk kedalam kategori baik dan meningkat dari siklus I ke siklus II. Hal ini terlihat dari rata-rata skor yang diperoleh dari dua orang pengamatan. Kemudian butir pengamatan yang belum dilakukan secara optimal di siklus I telah dapat diperbaiki pada siklus II selain itu dapat meningkatkan keterampilan proses sains siswa
1. Model pembelajaran inkuiri merupakan model pembelajaran yang sangat baik digunakan untuk meningkatkan keterampilan proses sains. Akan tetapi hendaknya setiap tahapan dari model pembelajaran inkuiri ini diperhatikan terutama tahapan mengumpulkan data. Tujuannya agar dapat mengarahkan siswa untuk melatih dan mengembangkan keterampilan proses sains yang mereka miliki.

2. Bagi peneliti selanjutnya agar dapat melakukan penelitian lebih lanjut mengenai keterampilan proses sains siswa ini dengan menambahkan indikator keterampilan proses lainnya dan menggunakan model pembelajaran lain.

\section{DAFTAR PUSTAKA}

Hosnan. 2014. Pendekatan Saintifik dan Kontekstual dalam Pembelajaran Abad 21. Bogor: Ghalia Indonesia.

Setyosari, Punaji. 2015. Metode Penelitian Pendidikan dan Pengembangan. Jakarta: Prenadamedia Group.

Sudijono, Anas. 2012. Pengantar Statistika Pendidikan. Jakarta: Rajawali Pers.

Sudijono, Anas. 2014. Pengantar Statistika Pendidikan. Jakarta: Rajawali Pers.

Trianto. 2012. Model Pembelajaran Terpadu. Jakarta: PT Bumi Aksara.

Trianto. 2014. Model Pembelajaran Terpadu. Jakarta: PT Bumi Aksara.

\section{Saran}


